\title{
Lament for a pirate's son
}

Previously published at www.cmaj.ca

$\mathrm{T}$ he last time she saw her little girl, the child hadn't wanted her to leave. But she had to get that diploma, if she was to get them out of their mess and have a chance at a better life. So he would babysit. It was just for a few hours. Who couldn't look after a three-year-old for a few hours?

Speechless, she sat there in a heap, unmoving on the coffeestained couch of the intensive care unit quiet room. Guilt percolated her every word. Through her tears, she recalled how, at the time of their first meeting, his bandana, torn jeans, curses and three-day stubble had led her daughter to enquire suspiciously whether he was a pirate... Now, in silence, the bitter irony of her child's imagery was plain.

"Did she suffer?"

What she wanted to hear was obvious. The answer I had was the opposite.

"No." I said, avoiding her eyes.

The girl had arrived in the emergency department extensively bruised, apneic and posturing; her hair soaking wet. His only explanation: that he had found her like that when he went to give her a kiss.

What happened during her mother's two-hour absence? Conjecture.

But her injuries, like the map to a well-guarded secret, walked me through the violent ordeal that preceded her death. Had she wanted to watch Cinderella instead of hockey? Had she had an accident? A bedtime tantrum? Or had she simply been looking for the attention he wouldn't provide?

The theories crowded my mind. The scenarios parade inside it like so many silent movies; the very thought of her cries so unbearable, it banishes the associated sound.

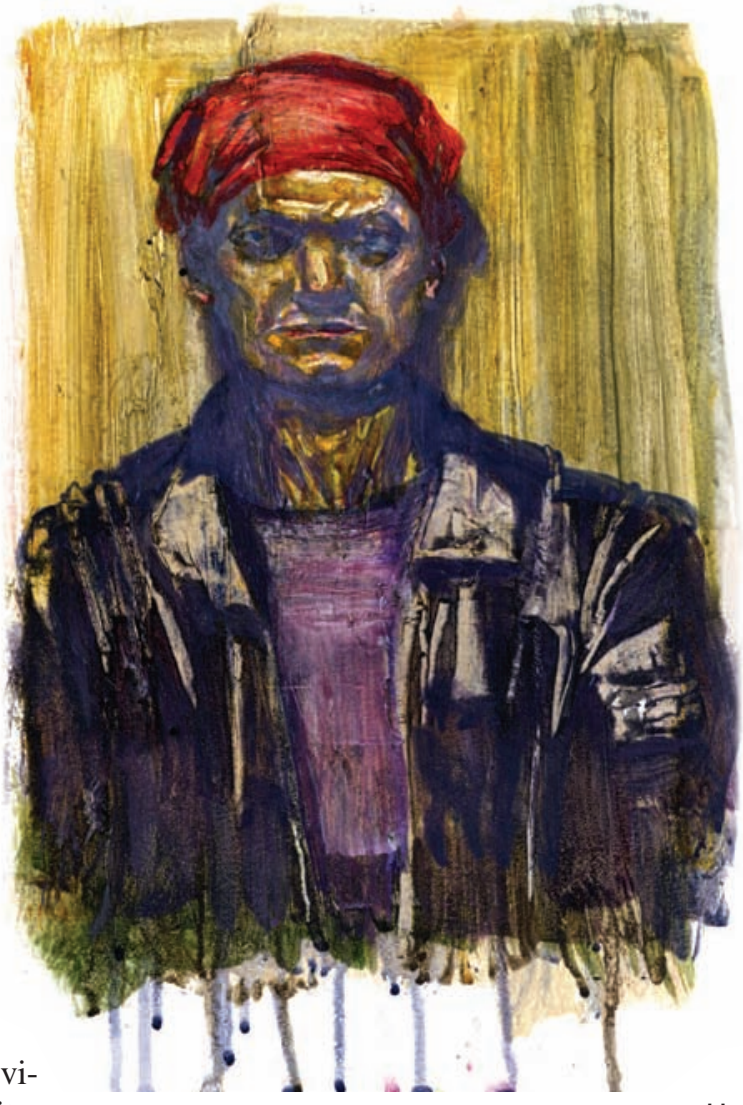

But she came back. Years later; she came back. Through him. What I thought was behind me lay ahead, once more. With a few more notches on his sword, he sailed back into our cove. We duelled, my cannons roared, but he never walked the plank. Battle-weary but still standing, he sailed away without remorse, aboard a sloop christened "Not Guilty."

Now as I watch from shore, I realize he is indeed a pirate. Her captain gone, in search of an anchor and blinded by the promise of love, she was adrift and he, her North Star. She let him board her ship, trusted him with her most precious treasure and, having taken what he wanted, pillaged lives and killed an innocent, he left her adrift amidst the flotsam of her life.

And on the wind a rumour blows: He has boarded yet another ship... and this time he has his very own, newborn cabin boy.

Of course she had suffered. Even her mother knew that. But why render something already so painful, excruciating?

For months, the girl haunted me daily. Her face, forever etched in my memory, surfaced at will. In my migraines, her anguish; in my insomnia, her terror; in my deepest fears... my own daughter's pale, naked body on a cold steel table. For as it happened, I did watch Cinderella: her breath in tandem with my own; her warm hand nestled in mine; her forehead soft under my lips. The same age. The same hair. The same eyes. A parallel unconsciously fashioned but evermore consciously suffered.

Then, as the memory of her became almost unbearable, she relented and came weekly... monthly... rarely... The storm moved on, the swells diminished, the pink night skies returned upon calm seas.
How I fear for him. And yet, with all I know, how helpless I am to protect him. Eternal Father, strong to save Whose arm hath bound the restless wave.

Who bidd'st the mighty ocean deep Its own appointed limits keep Oh hear us when we cry to thee For those in peril on the sea.

\section{Steven Bellemare MD \\ Child abuse pediatrician \\ Ottawa, Ont.}

The people and events depicted in this article are fictional.

\section{REFERENCE}

1. Whiting W. Eternal father, strong to save. In Voices United: the hymn and worship book of the United Church of Canada. Toronto (ON); The United Church Publishing House; 2007. p. 659. 